\title{
Cadmium in the Umtata River and the associated health impact of on rural communities who are primary users of water from the river
}

\author{
OS Fatoki ${ }^{\star *}$, OR Awofolu² and B Genthe ${ }^{3}$ \\ ${ }^{1}$ Research \& Development Office, University of Venda, Thohoyandou, South Africa \\ ${ }^{2}$ Department of Chemistry, University of Fort Hare, Alice 5700, South Africa \\ ${ }^{3}$ Environmentek, CSIR, Stellenbosch, South Africa
}

\begin{abstract}
Trace levels of Cd were determined in Umtata River which may affect human health. The levels of Zn were also determined since $\mathrm{Zn}$ can provide partial protection against the toxic effect of $\mathrm{Cd}$ in humans. The levels of $\mathrm{Cd}$ varied between trace and $0.007 \mathrm{mg} / \ell$ while that of $\mathrm{Zn}$ ranged from trace to $0.019 \mathrm{mg} / \ell$. Generally the levels of $\mathrm{Cd}$ and $\mathrm{Zn}$ found in the river were below the South African water quality guidelines for $\mathrm{Cd}$ and $\mathrm{Zn}$, respectively. The hazard quotients for $\mathrm{Cd}$ in the river were calculated in order to show the potential health risks of cadmium to local primary users of water from river and the values were within acceptable limits.
\end{abstract}

Keywords: cadmium, river water, health risk

\section{Introduction}

The Umtata River rises in the plateau region of the Eastern Cape, approximately midway between the Drakensberg escarpment and the sea (Fig. 1). The catchment of the river itself is some $100 \mathrm{~km}$ long and up to $50 \mathrm{~km}$ in breadth. The geology of the catchment is constituted by mudstones and sandstones of the Beaufort Group from the headwaters to about $30 \mathrm{~km}$ from the coast, and thence, by shales, mudstones and sandstones of the Ecca Group, with exposures of dolerite intrusions mostly in the higher lying areas (DWAF, 1998a).

The Umtata River provides water and a conduit for effluent disposal in a densely populated area of the Eastern Cape. Water from the Umtata River is used for various purposes by a large population of the Transkei, most of which is rural - domestic (cooking, drinking and washing), agricultural (that is, livestock watering, irrigation is rarely done in the catchment), and recreational purposes (swimming). Other uses such as aquaculture (fishery) and industrial (cooling of engines in the wood industry) are less significant (Fatoki and Muyima, 2003). One of its major uses is domestic (Fatoki and Muyima, 2003) but is the water fit for its intended uses? The accumulation of metals in an aquatic environment has direct consequences to man and the ecosystem. Cadmium is a common environmental pollutant, which is widely distributed in the aquatic environment. Its sources are mainly from weathering of minerals and soils (Merian 1991); atmospheric deposition from non-ferrous metal mines, smelters and refineries; coal combustion, refuse incineration and iron and steel industries (Merian, 1991); industrial effluents (Prater, 1975); domestic effluents (Preuss and Kollman, 1974); urban storm-water runoff (Field and Lager, 1975) and spoil heaps (Heitfield and Schottler, 1973). The concentration of Cd in unpolluted water is usually less than $0.001 \mathrm{mg} / \ell$. The South African

* To whom all correspondence should be addressed.

畐+2715 962-8504; fax:+2715 962-8439; e-mail: fatoki@univen.ac.za

Received 19 April 2004; accepted in revised form 15 July 2004. guideline for Cd is $0.005 \mathrm{mg} / \ell$ (DWAF, 1996, 1998b).

The water quality situation in the Umtata River regarding Cd has always been cause for concern. The results of a pollution study on Umtata River done between May 1999 and March 2002 (Fatoki and Muyima, 2003) indicated high levels of Cd in the river ranging from $0.01 \mathrm{mg} / \ell$ to $0.08 \mathrm{mg} / \ell$ for representative data (Table 5), which is an order of magnitude higher than the guideline value. Probable sources of Cd in the catchment at the time include:

- Chemical waste discharge from a wood processing factory situated near the source of the river (however the head of factory denied ever discharging waste directly into the river).

- Urban runoff.

- Nickel-cadmium based batteries from the rural communities that had been disposed of in the waste disposal sites.

- Runoff from runoff from agricultural soils in the catchment that used phosphate fertilisers ( $\mathrm{Cd}$ is a common impurity in phosphate fertilisers).

- Effluent discharge from Umtata Sewage Treatment Plant.

- Natural source due to the geology of the catchment.

The high levels of Cd in the river have given rise to worries that water supplied from the river will be unfit for domestic use and may impact on the "health" of the communities that live on the river banks that depend on it primarily for their domestic water supply.

The following recommendations were then made aimed at preventing or reducing Cd pollution in the Umtata River:

- Monitoring and removal of wastes close to the river banks.

- Management of agricultural practices in such a way as to control the use of pesticides and fertilisers.

- A valid permit to be obtained by the Umtata Sewage Treatment Plant to comply with DWAF effluent regulations according to the National Water Act, 1998.

- Development and implementation of routine education programmes to the rural community on the need to prevent pollution of the river. 


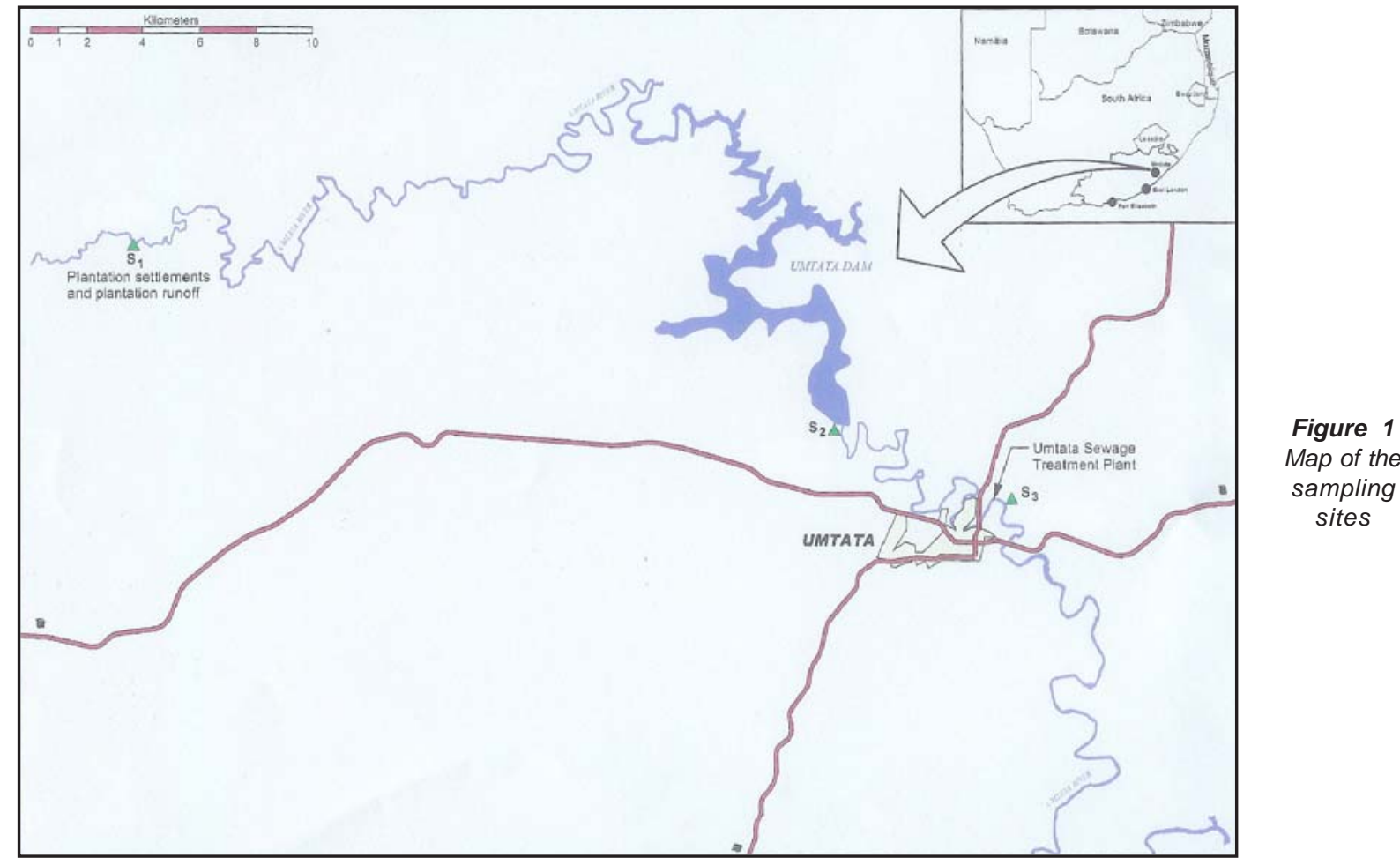

Also, as an intervention programme to manage the pollution of the river, a workshop was conducted for all stakeholders in the catchment on actions to take to reduce pollution of the river. The workshop was well attended and the need to implement the recommendations in the report was impressed on them.

The worry about the possible health effects of $\mathrm{Cd}$ on the community in the catchment that uses the river directly for primary domestic purposes necessitates this re-investigation.

Adequate $\mathrm{Zn}$ intake by humans tends to provide partial protection against toxic effects of Cd (DWAF, 1996) and because of this Zn was studied along with Cd levels. Metals like Cd and Zn are most likely to have increased detrimental environmental effects as a result of lowered pH (DWAF, 1996). Temperatures at which a sample is collected and at which physico-chemical measurements are made are also important for data correlation and interpretation purposes. For domestic use high temperature may increase the toxicity of heavy metals in waters (Van Loon, 1982; Dojlildo and Best, 1993). Thus $\mathrm{pH}$ and temperature were measured in addition.

Risk assessment and risk communication lead into the risk management process, which allows for good environmental health decision-making. The health-risk assessment approach briefly involves the following:

Hazard identification, where potential contaminants of concern and their effects on human health are identified.

Dose-response assessment, which collects data on the relationship between the amount of hazardous substance taken into the body and the onset of adverse health effects. Dose-response data provide a quantitative basis for assessing health risks.

Exposure assessment, which establishes the pathways along which contaminants may be released, and the intensity, frequency and duration of human contact with a particular contaminant.

Risk characterisation, which provides an indication of the likeli- hood of adverse health effects from a given exposure to a contaminant of concern. Quantitative methods of risk characterisation derive numerical estimates of risk, while qualitative techniques are used to rank health risks where data are insufficient for quantitative calculations.

The adverse health effects of chronic exposure to Cd include kidney damage (Herber et al., 1988) and aches and pains in bones (Itai-itai disease) (Tsuchiya, 1978; Kjellstroem, 1986). Cadmium is also suspected of having mutagenic, carcinogenic and teratogenic effects (Fischer, 1987; Kazantzis, 1987) and recently it has been classified as an endocrine disruptor. Studies have also shown that the offspring of animals exposed to Cd during pregnancy experienced behavioural changes and learning disabilities (NJDHSS, 1999; ATSDR, 1999).

For risk assessment purpose, the dose at which it is thought that no adverse effect occurs is based on the assumption that a threshold exists for toxic effects. A dose is expressed as units of $\mathrm{mg} / \mathrm{kg} \cdot \mathrm{d}$ (Thistle Publishing, 1995). In general, the 'safe' reference dose (RfD) is an estimate of a daily exposure to a human population that is likely to be without deleterious effects over a lifetime. The population includes sensitive subgroups, with a possible order of magnitude uncertainty (Hampshire Research Institute, 1995).

Commonly used benchmarks used to describe dose-response relationships are:

- Reference dose (RfD): The pollutant level that can be ingested over a specified time period without toxic health effects occurring.

- No-observed-adverse-effect level (NOAEL): The highest exposure level at which there are no statistically or biologically significant increases in the frequency or severity of adverse effects between the exposed population and an appropriate control population.

- Lowest-observed-adverse-effect level (LOAEL): The lowest exposure level at which there are statistically or biologically 
significant increases in frequency or severity of adverse effects between the exposed population and its appropriate control group.

- Minimal risk level (MRL): An estimate of daily human exposure to a substance that is likely to be without an appreciable risk of adverse toxic effects over a specified duration of exposure. MRLs can be derived for acute, intermediate, and chronic duration exposures by the inhalation and oral routes.

According to the USEPA (1989), the RfD for Cd in drinking water is $0.0005 \mathrm{mg} / \mathrm{kg} \cdot \mathrm{d}$ (IRIS, 2003). In other words, a $70 \mathrm{~kg}$ person can safely consume $0.035 \mathrm{mg}$ ( or $35 \mu \mathrm{g}$ ) Cd per day without any adverse effects expected, whereas the estimated lethal oral dose for humans is 350 to $3500 \mathrm{mg}$ of Cd dose (WHO, 1996), i.e. 10000 times the reference dose.

Exposure assessment is a key phase in health risk assessment, because without exposure, even the most toxic or carcinogenic compound is not hazardous. Exposure assessment involves the identification of potential receptors, exposure pathways, exposure media and receptor behaviour, which affects exposure duration (USEPA, 1989).

For human health risk assessment, the receptors are generally members of the public who may be exposed to hazardous substances. In this instance it would focus on resident communities in the area making use of river water as a source for domestic purposes. This study re-investigated the levels of Cd in the river and assessed the health risk of $\mathrm{Cd}$ in the river to communities along the banks of the river who rely on it as their primary domestic source.

\section{Methodology}

\section{Calibration curves and blank determinations for metal analysis in water samples}

Cd: Normal concentration of $\mathrm{Cd}$ in freshwater is $0.005 \mathrm{mg} / \ell$ (DWAF, 1996). However, concentrations as high as up to $0.1 \mathrm{mg} / \ell$ could be found where there is contamination. Calibration standards in the range of 0 to $0.1 \mathrm{mg} / \ell \mathrm{Cd}$ were therefore prepared using 1000 $\mathrm{mg} / \ell \mathrm{Cd}$ standard solution with $\left.\mathrm{Cd}(\mathrm{NO} 3)_{2} \cdot 4 \mathrm{H}_{2} \mathrm{O}\right)$, supplied by BDH laboratory, England and diluted to the required concentrations with doubly distilled water. Blank determination was done using the doubly distilled water, which gave a clean background.

Zn: Normal concentration of $\mathrm{Zn}$ in freshwater sources is $3 \mathrm{mg} / \ell$ (DWAF, 1996) but concentration up to $10 \mathrm{mg} / \ell$ is not uncommon. Therefore calibration standards in the range 0 to $10 \mathrm{mg} / \ell \mathrm{Zn}$ was prepared from $1000 \mathrm{mg} / \ell \mathrm{Zn}$ stock standard solution using standard $\mathrm{ZnCl}_{2}$ with doubly distilled water. This initial concentration was suitably diluted with distilled water. Blank determinations were also performed with the doubly distilled water, which gave a clean background.

\section{Detection limits and the determination of percentage recoveries of the elements from spiked water samples for quality assurance}

The detection limits for each of the elements were determined using the lowest concentration of each of the elements that gave the least detectable signal by the flame AAS for Cd and Zn (DAWF, 1992). Six replicates each of these concentrations were prepared and analysed. The detection limits were determined from $3 \delta(\delta=$ standard deviation) of the replicate determinations for each element (Miller and Miller, 1998).
TABLE 1

Detection limits (mg/l) and percentage recoveries for $\mathrm{Cd}$ and $\mathrm{Zn}$ from water samples

\begin{tabular}{|c|c|c|c|}
\hline Element & $\begin{array}{l}\text { Detection } \\
\text { limits } \\
(\mathrm{mg} / \mathrm{l})\end{array}$ & $\begin{array}{l}\text { a\% Recove- } \\
\text { ries } \pm S . D^{*}\end{array}$ & $\begin{array}{l}\text { b\% Recove- } \\
\text { ries } \pm \mathrm{SD}^{*}\end{array}$ \\
\hline Cd & 0.001 & $90.67 \pm 6.80$ & $83.33 \pm 5.73$ \\
\hline $\mathrm{Zn}$ & 0.006 & $90.47 \pm 0.29$ & $88.17 \pm 3.09$ \\
\hline \multicolumn{4}{|c|}{$\begin{array}{l}\text { a - Open beaker digestion method (DWAF, 1992) } \\
\text { b - Extractive concentration method (Van Loon, 1982) } \\
\text { SD - Standard deviation } \\
\text { * - Average of } 3 \text { replicate analyses }\end{array}$} \\
\hline
\end{tabular}

The quality assurance studies were performed with distilled water samples by spiking method at fortification levels of 0.005 $\mathrm{mg} / \ell$ for $\mathrm{Cd}$ and $10 \mathrm{mg} / \ell$ for $\mathrm{Zn}$. The open beaker digestion method (DWAF, 1992) was initially employed for Cd and Zn before employing the comparative extractive concentration method with amino pyrolidine dithiocarbamate(APDC) as complexing agent and methyl isobutyl ketone (MIBK) as the extracting solvent (Van Lon, 1982) for the metals (Cd and Zn). Determination was by flame AAS. Recoveries were calculated from the ratio of the amount of the element (s) recovered after spiking to the amount added. Three replicate analyses were done for each element for water samples collected.

\section{Sampling sites}

The sampling sites along the rivers and the dams are shown in Fig. 1. The sites were chosen due to their easy accessibility and they also reflect different activities in the catchments, which may affect the quality situation in the river. Samples were taken between October 2002 and March 2003.

Before sampling for chemical analysis, sample bottles were cleaned by soaking in detergent for $24 \mathrm{~h}$., followed by rinsing several times with tap water until free of detergent, rinsed with $5 \%$ nitric acid and then thoroughly with distilled-deionised water (DWAF, 1992; DWAF, 1999).

Water samples were collected in clean plastic bottles from the river according to the standard procedures described in the sampling guide (DWAF, 1992; DWAF, 1999). Samples for metal analyses were preserved with $5 \mathrm{~m} \ell$ conc. $\mathrm{HNO}_{3}$. After collection the samples were kept at about $4^{\circ} \mathrm{C}$ until analysed.

\section{Analyses of water samples for metals (Cd and $\mathrm{Zn}$ ), pH and temperature}

Total metal contents (Cd and $\mathrm{Zn}$ ) of water samples were analysed by the open beaker digestion method (DWAF, 1992) as it gave better recoveries and better repeatability than the extractive concentration method (Van Loon, 1982). Three replicate analyses were done for each element for each of water samples collected. Temperature (determined on site) and $\mathrm{pH}$ (with un-acidified water samples) were determined using the Merck (Pty Ltd) 330 pH meter.

\section{Health risk assessment}

The health risk assessment methodology that was used was the one recommended by the US Environmental Protection Agency (USEPA, 
TABLE2

$\mathrm{Cd}$ and $\mathrm{Zn}$ levels ${ }^{* *}$ in the Umtata River (mg/l) for water samples taken between October 2002 and December 2003

\begin{tabular}{|c|c|c|c|c|c|}
\hline $\begin{array}{l}\text { Sampling } \\
\text { sites }^{\star \star *}\end{array}$ & $\begin{array}{l}\text { Sampling } \\
\text { dates }\end{array}$ & Cd & $\mathrm{Zn}$ & $\mathrm{pH}$ & $\begin{array}{l}\text { Temp. } \\
{ }^{\circ} \mathrm{C}\end{array}$ \\
\hline $\mathrm{S}_{1}$ & 29/10/2002 & $0.002 \pm 0.001$ & $0.110 \pm 0.06$ & 6.7 & 23.2 \\
\hline $\mathrm{S}_{2}$ & 29/10/2002 & $0.003 \pm 0.001$ & $0.161 \pm 0.06$ & 7.1 & 23.5 \\
\hline $\mathrm{S}_{3}$ & 29/10/2002 & $0.003 \pm 0.001$ & $0.053 \pm 0.01$ & 6.5 & 20.4 \\
\hline $\mathrm{S}_{1}$ & 23/11/2002 & $0.006 \pm 0.001$ & $0.019 \pm 0.01$ & 7.2 & 22.2 \\
\hline $\mathrm{S}_{2}$ & 23/11/2002 & $0.007 \pm 0.003$ & $0.019 \pm 0.01$ & 5.9 & 21.5 \\
\hline $\mathrm{S}_{3}^{2}$ & 23/11/2002 & $0.007 \pm 0.002$ & $0.090 \pm 0.07$ & 6.0 & 21.8 \\
\hline $\mathrm{S}_{1}$ & $15 / 02 / 2003$ & Trace & $0.035 \pm 0.05$ & 6.8 & 23.7 \\
\hline $\mathrm{S}_{2}$ & $15 / 02 / 2003$ & Trace & $0.085 \pm 0.12$ & 6.9 & 22.5 \\
\hline $\mathrm{S}_{3}$ & $15 / 02 / 2003$ & $0.004 \pm 0.005$ & $0.073 \pm 0.05$ & 6.3 & 23.2 \\
\hline $\mathrm{S}_{1}$ & 04/11/03 & $0.002 \pm 0.002$ & $0.04 \pm 0.002$ & 6.7 & 23.5 \\
\hline $\mathrm{S}_{2}$ & $04 / 11 / 2003$ & $0.005 \pm 0.002$ & $0.03 \pm 0.010$ & 6.8 & 24.6 \\
\hline $\mathrm{S}_{3}^{2}$ & 04/11/2003 & $0.002 \pm 0.002$ & $0.04 \pm 0.003$ & 6.1 & 24.1 \\
\hline $\mathrm{S}_{1}$ & $24 / 11 / 2003$ & $0.002 \pm 0.002$ & $0.02 \pm 0.001$ & 6.2 & 24.2 \\
\hline $\mathrm{S}_{2}$ & $24 / 11 / 2003$ & $0.004 \pm 0.002$ & $0.05 \pm 0.010$ & 6.4 & 23.6 \\
\hline $\mathrm{S}_{3}$ & $24 / 11 / 2003$ & $0.005 \pm 0.002$ & $0.06 \pm 0.030$ & 6.5 & 22.8 \\
\hline $\mathrm{S}_{1}$ & 08/12/2003 & $0.002 \pm 0.001$ & Trace & 7.1 & 25.8 \\
\hline $\mathrm{S}_{2}$ & 08/12/2003 & $0.002 \pm 0.001$ & $0.02 \pm 0.002$ & 6.6 & 22.6 \\
\hline $\mathrm{S}_{3}$ & 08/12/2003 & $0.004 \pm 0.001$ & $0.02 \pm 0.001$ & 6.3 & 19.4 \\
\hline \multicolumn{6}{|c|}{$\begin{array}{l}* *=\text { Average of three replicate samples } \\
* * *-\mathrm{S}_{1}=\text { near the source, } \mathrm{S}_{2}=\text { Midstream at Umtata Dam and } \mathrm{S}_{3}=\text { downstream (after the Umtata } \\
\text { Sewage Treatment Plant effluent discharge point). } \\
\text { Trace }=<\text { detection limit }\end{array}$} \\
\hline
\end{tabular}

TABLE 3

Representative data (mg/l) from the results of the first study for the Umtata River (May 1999 - March 2000)

\begin{tabular}{|c|c|c|c|c|c|c|c|c|c|}
\hline Sampling sites & $18 / 5 / 99$ & 18/6/99 & $12 / 8 / 99$ & $23 / 9 / 99$ & $29 / 10 / 99$ & $8 / 12 / 99$ & $20 / 01 / 00$ & $10 / 2 / 00$ & $01 / 3 / 00$ \\
\hline $\mathrm{S}_{1}$ (near the source) & 0.02 & 0.02 & 0.01 & 0.01 & 0.02 & 0.02 & 0.02 & 0.01 & 0.04 \\
\hline $\mathrm{S}_{2}$ (midstream at Umtata Dam) & 0.04 & 0.05 & 0.04 & 0.06 & 0.02 & 0.03 & 0.02 & 0.03 & 0.01 \\
\hline $\begin{array}{l}\mathrm{S}_{3} \text { (downstream, after the Umtata Sewage } \\
\text { Treatment Plant discharge point) }\end{array}$ & 0.05 & 0.03 & 0.12 & 0.05 & 0.03 & 0.07 & 0.03 & 0.08 & 0.07 \\
\hline
\end{tabular}

1989). This protocol was originally intended to accommodate carcinogen assessments. However, current trends favour the application of similar procedures to chemical toxicants. In the evaluation of the chronic non-carcinogenic health effects from oral or dermal exposures, the average daily dose (ADD) received during the period of exposure is compared to the reference dose.

The Cd concentrations that were used to calculate the exposure doses were those measured at 3 sampling sites along the Umtata River (Fig.1), namely $\mathrm{S}_{1}, \mathrm{~S}_{2}$ and $\mathrm{S}_{3}$ (presented in Tables 2 \&3). The Health Risk Assessment Programme Risk*Assistant ${ }^{\text {TM }}$ (Hampshire Research Institute, 1995) was employed to calculate the potential exposure concentrations (doses).

As this was a preliminary screening health risk assessment the exposure assessment presented simply examined the potential health effects of a representative adult and a representative child living in the vicinity of the Umtata River using the river water as their sole source for domestic purposes. Exposures that were considered in the assessment included:

- Ingestion via drinking, including accidental ingestion during recreational activity and bathing

- Dermal absorption due to washing/bathing activities

- Consumption of fish and shellfish caught in the river.

In a quantitative human health risk assessment, numerical estimates of human exposures are expressed in terms of: 
- Average daily dose(ADD) for toxic effects. This is the amount of substance taken into the body on a daily basis during the exposure period and is calculated from the expression:

$A D D=\frac{\left(C_{\text {medium }} \times I R \times E D \times F_{c}\right)}{B W \times A T}(\mathrm{mg} / \mathrm{kg} . \mathrm{d})$ where:

$\mathrm{C}_{\text {medium }}$ is the concentration in the contaminated medium (e.g. water)

IR is the daily intake rate

ED is the exposure duration

$\mathrm{F}_{\mathrm{c}}$ the fraction contaminated

BW, the body weight

AT, the lifetime averaging time.

A number of exposure parameters needed to be assigned to the exposure concentration calculation and are presented in the following two subsections.

\section{Exposure parameters used to calculate exposure estimates}

The dose (or exposure concentration) values presented in this assessment reflect not only the concentrations of contaminant in various environmental media and the exposure pathways selected for analysis, but also the specific numerical parameters applied to each exposure scenario. Different exposure pathways can lead to differing degrees of severity in health effects for the same chemical substance. Table 4 summarises the exposure parameters used in this assessment.

\section{Potential health risks associated with the domestic use of the river water? (risk characterisation)}

Risks were calculated for exposure to Cd assuming that people were making use of the river water as their sole source for domestic purposes.

For toxic chemicals, a hazard quotient (HQ) is calculated, which compares the expected exposure to the agent to an exposure that is assumed not to be associated with toxic effects. For oral or dermal exposures, the average daily dose (ADD) is compared to a reference dose (RfD):

\section{H.Q. = average daily dose / reference dose}

The hazard quotients ${ }^{* * * *}$ calculated using exposure parameters to Cd through use of Umtata River water for a lifetime exposure, representing 26 different possible exposures as described in the text are shown in Table 5.

\section{Results and discussion}

The results of the detection limits and the percentage recoveries of $\mathrm{Cd}$ and $\mathrm{Zn}$ from fortified river water samples are shown in Table 1 . The results of the metal levels in water samples from Umtata River are shown in Table 2. Results of the hazard quotients calculated using exposure parameters to $\mathrm{Cd}$ through use of Umtata River water for a lifetime exposure, representing 26
TABLE4

xposure parameters used to generate exposure dose estimates

Parameters used in exposure assessment for calculation of cadmium dose

\begin{tabular}{|l|l|l|}
\hline $\begin{array}{l}\text { Specific } \\
\text { parameters }\end{array}$ & Adult & Child \\
\hline Body weight & $70 \mathrm{~kg}$ & $24 \mathrm{~kg}$ \\
\hline Lifetime: & 70 years & 70 years \\
\hline Exposure period & 30 years & 6 years \\
\hline Drinking water & $\begin{array}{l}350 \text { events/yr } \\
2 \ell \text { per event } \\
100 \% \text { fraction contaminated }\end{array}$ & $\begin{array}{l}350 \text { events per/yr } \\
100 \% \text { fraction contaminated }\end{array}$ \\
\hline Showering & $\begin{array}{l}350 \text { events/yr } \\
0.2 \text { h per event }\end{array}$ & $\begin{array}{l}350 \text { events per/yr } \\
0.2 \text { h per event }\end{array}$ \\
\hline Fish and shellfish & $\begin{array}{l}350 \text { events per/yr } \\
0.054 \text { kg per event } \\
100 \% \text { fraction contaminated }\end{array}$ & $\begin{array}{l}350 \text { events/yr } \\
100 \% \text { fraction contaminated }\end{array}$ \\
\hline Swimming & $\begin{array}{l}7 \text { events per/yr } \\
2.7 \mathrm{~h} \text { per event } \\
50 \text { m } \ell \text { accidental ingestion, } \\
100 \% \text { fraction contaminated }\end{array}$ & $\begin{array}{l}50 \text { m } \ell \text { accidental ingestion } \\
100 \% \text { fraction contaminated } \\
2.40 \text { events per/yr }\end{array}$ \\
\hline
\end{tabular}

\begin{tabular}{|c|c|c|c|c|c|}
\hline \multicolumn{6}{|c|}{$\begin{array}{l}\text { TABLE5 } \\
\text { Hazard quotients } \\
\text { to cadmium through use of Umtata River water for a lifetime } \\
\text { exposure, representing } 26 \text { different possible exposures } \\
- \text { as described in the text }\end{array}$} \\
\hline \multicolumn{3}{|c|}{$\begin{array}{l}\text { Results from May } 1999 \text { - } \\
\quad \text { March } 2000\end{array}$} & \multicolumn{3}{|c|}{$\begin{array}{l}\text { Results from October } 2002 \\
\text { - December } 2003\end{array}$} \\
\hline \multirow{2}{*}{$\begin{array}{c}\mu \mathrm{g} / \mathrm{l} \\
\text { cadmium } \\
\text { in river } \\
\text { water }\end{array}$} & \multicolumn{2}{|c|}{ Hazard quotient } & \multirow{2}{*}{$\begin{array}{c}\mu g / \ell \\
\text { cadmium } \\
\text { in river } \\
\text { water }\end{array}$} & \multicolumn{2}{|c|}{ Hazard quotient } \\
\hline & $\begin{array}{c}\text { Adult } \\
\text { exposure }\end{array}$ & $\begin{array}{c}\text { Child } \\
\text { exposure }\end{array}$ & & $\begin{array}{c}\text { Adult } \\
\text { exposure }\end{array}$ & $\begin{array}{c}\text { Child } \\
\text { exposure }\end{array}$ \\
\hline 10 & 1.8 & 1.2 & 2 & 0.35 & 0.2 \\
\hline 20 & 3.5 & 2.3 & 3 & 0.52 & 0.4 \\
\hline 40 & 7.0 & 4.6 & 4 & 0.70 & 0.5 \\
\hline 50 & 8.7 & 5.8 & 5 & 0.87 & 0.6 \\
\hline 60 & 10.5 & 7.0 & 6 & 1.05 & 0.7 \\
\hline 70 & 12.2 & 8.1 & 7 & 1.22 & 0.8 \\
\hline 80 & 14.0 & 9.3 & & & \\
\hline \multicolumn{6}{|c|}{$\begin{array}{l}\text { **** - Hazard quotients that exceed } 1.0 \text { indicate the possibility of } \\
\text { non-cancer toxic risks from the exposure. }\end{array}$} \\
\hline
\end{tabular}

different possible exposures are shown in Table 5.

The detection limits for the heavy metals by flame AAS were $0.001 \mathrm{mg} / \ell$ for $\mathrm{Cd}$ and $0.006 \mathrm{mg} / \ell$ for $\mathrm{Zn}$. The mean \% recovery of Cd from spiked water samples was $90.67 \pm 6.80 \%$ and for Zn, 90.47 
$\pm 0.29 \%$ by open beaker digestion method(DWAF, 1992) and 83.33 $\pm 5.73 \%$ for $\mathrm{Cd}$ and $88.17 \pm 3.09 \%$ for $\mathrm{Zn}$ using the extractive concentration method (Van Loon, 1982). Thus the open digestion method gave better recoveries and was therefore tested on environmental water samples for $\mathrm{Cd}$ and $\mathrm{Zn}$.

The concentration of $\mathrm{Cd}$ in the river water samples ranged from trace to $0.007 \mathrm{mg} / \ell$ in Umtata River. The levels of $\mathrm{Zn}$ also varied between trace and $0.0 .019 \mathrm{mg} / \ell$ (Table 2 ). The $\mathrm{pH}$ values varied between 5.9 and 7.2 while the temperature ranged from $19.4^{\circ} \mathrm{C}$ to $24.6^{\circ} \mathrm{C}$.

The hazard quotients (Table 5) calculated from Cd levels in the study between October 2002 and December 2003 shown in Table 2 varied between 0.2 to 0.8 for a hypothetical child exposure and between 0.35 and 1.22 for a hypothetical adult exposure. The hazard quotients (Table 5) calculated from representative data from the earlier study of May 1999 to 2000 shown in Table 3 ranged from 1.2 to 9.3 for the hypothetical child exposure and from 1.8 to 14.0 for the hypothetical adult exposure indicating potential health risks as a result of this adult exposure.

The levels of Cd detected in the water samples from Umtata River fell within the SA guideline of $0.005 \mathrm{mg} / \ell$ (DWAF, 1996) in water for domestic use (with one exception, i.e., river water containing $0.007 \mathrm{mg} / \ell \mathrm{Cd}$ ). The levels of $\mathrm{Zn}$ were also below the SA guideline of $3 \mathrm{mg} / \ell$ for water for domestic use (DWAF, 1996). At these levels of $\mathrm{Zn}$ in the river it would not cause any adverse effect on the users of water from the river for domestic purposes. The $\mathrm{pH}$ and temperature values also seemed to fall within the normal levels (DWAF, 1996).

Elevated Cd levels were detected in the Umtata River during the execution of a previous WRC project (Fatoki and Muyima, 2003) with concentrations ranging from 0.01 to $0.08 \mathrm{mg} / \ell$ from representative data from previous sampling locations (Table 3). Many probable sources of the Cd were identified, and an intervention programme was carried out to reduce Cd pollution. The results of this new study have shown the Cd levels to be reduced by an order of magnitude, with concentrations now falling within acceptable range.

The hazard quotients calculated and presented in the Table 5 indicate that the concentrations of Cd found in the Umtata River during May 1999 to March 2000 result in exceptionally high hazard quotients which indicate that if people were using the water for domestic purposes, adverse health effects would occur. The next sampling run, which took place in October 2002 to December 2003, indicated acceptable hazard quotients (with one exception, i.e. river water containing $0.007 \mathrm{mg} / \ell \mathrm{Cd}$ ) of $\mathrm{Cd}$.

The greater part of the anticipated adverse health effects arose as a result of the ingestion of fish or shellfish (approximately 60\% of the calculated dose is as a result of assuming exposure via ingestion of fish/shellfish - data not shown).

If one were to assume that no fish or shellfish were consumed, the anticipated health risks would be significantly reduced. This effect would be most significant for the exposure calculations during the $2^{\text {nd }}$ sampling run between October 2002 and December 2003. The Cd concentrations detected in the first sampling run (May 1999 to March 2000) even though reduced, would remain unacceptably high, with high hazard quotients in almost all Cd concentrations measured during that time, even if the consumption of fish/shellfish were to be excluded from the dose calculations.

The remedial actions taken following the 1999 to 2000 sampling appeared to have been successful in reducing the Cd levels in the Umtata River water and have therefore resulted in reducing the potential health effects. It is only when Cd levels exceed 0.006 $\mathrm{mg} / \ell$ that possible adverse health effects could be anticipated for humans using the river water as their sole source for domestic purposes. The bulk of the source of the anticipated health risk is derived from the ingestion source (drinking water and ingestion of fish from the river), with a small proportion of the estimated risk being as a result of dermal exposure.

There is no quantitative value for the carcinogenic potential of $\mathrm{Cd}$, as insufficient evidence exists to calculate the potency factor, therefore no quantitative risk results can be presented. It is generally assumed however that carcinogenic risks are zero only when exposure is zero.

All risk estimates involve some degree of uncertainty. Uncertainty in the health risk assessment process exists at numerous levels. Uncertainty regarding exposure has two primary sources: uncertainty about contamination including concentrations of chemicals to which the potential population may be exposed over the duration of the exposure period, and uncertainty about the exposed population. In this study both of these were significant. The exposed population was not studied and the health risk assessment is based solely on hypothetical exposure scenarios. Therefore uncertainty in the results will be substantial.

\section{Conclusion}

The levels of Cd in the Umtata River appeared to fall within acceptable levels and the intervention programme embarked upon after the first study appeared to have worked. If people were to use the water now for domestic purposes, adverse effects would not be anticipated.

\section{References}

ATSDR (1999) Agency for Toxic Substances and Disease Registry, Toxicological Profile for Cadmium. US Department of Health and Human Services, Atlanta, Georgia, USA.

DWAF (1986) Management of Water Resources of the Republic of South Africa. Department of Water Affairs and Forestry, Pretoria.

DWAF (1992) Analytical Methods Manual, TR 151. Department of Water Affairs and Forestry, Pretoria.

DWAF (1996) Water Quality Guidelines, Domestic Use (2nd edn.) Vol. 1. Department of Water Affairs and Forestry, Pretoria.

DWAF (1998a) Umtata River Catchment Preliminary Framework for the Development of an Integrated Catchment Management Plan. Report by Ninham Shand Consulting Engineers. Department of Water Affairs and Forestry, Pretoria.

DWAF (1998b) Quality of Domestic Water Supplies. Assessment Guide (2nd edn.) Vol. 1. Department of Water Affairs \& Forestry, Department of Health and Water Research Commission.

DWAF (1999) Quality of Domestic Water Supplies. Sampling Guide. (Vol. 2) Department of Water Affairs \& Forestry, Department of Health and Water Research Commission.

DOJLILDO JR and BEST GA (1993) Chemistry of Water and Water Pollution. Ellis Horwood Ltd, Great Britain.

FATOKI OS and MUYIMA NYO (2003) Situation Analysis of the Health-Related Water Quality Problems of the Umtata River. Report No. 1067/1/03, Water Research Commission, Pretoria.

FEILD RA and LAGER TA (1975) Urban runoff pollution controlstate-of-the-art. J. Environ. Eng. Div. ASCE 101 EE-1 107-125.

FISCHER AB (1987) Mutagenic effects of cadmium alone and in combination with antimutagenic selenite. Proc. $6^{\text {th }}$ Int. Conf. on Heavy Metals in the Environment (Vol. 2). New Orleans. CEP Consultants Ltd, Edinburgh. 112-114.

HAMMER MJ (1975) Water and Wastewater Technology. John Wiley \& Sons, Inc.

HAMPSHIRE RESEARCH INSTITUTE (1995) The Health Risk Assessment Programme Risk ${ }^{*}$ Assistant ${ }^{\mathrm{TM}}$. Thistle Publishing. 
HEITFELD KH and SCHOTTLER U (1973) Verackert wohin? Kontamination des Wassers in Bereich von Abfallhalden durch Spurenmetalle. Umwelt 1 57-58.

HERBER FRM, VERSCHOOR MA AND WIBOWO AAE (1988) A review of the kinetics and kidney effects of cadmium - Recent epidemiological studies. In: Hutzinger O and Safe SH: Environmental Toxins. (Vol. 2) Cadmium. Stoeppler M and Piscator M (eds.) Springer, Berlin-Heidelberg. New-York-London-Paris-Tokyo. 115-133.

IRIS (2003) Integrated Risk Information System. US Environmental Protection Agency.

KAZANTIS G (1987) The mutagenic and carcinogenic effect of cadmium. An update. J. Toxicol. Environ. Chem. 15 83-100.

KJELLSTROEM T (1986) Itai-itai Disease. In: Friberg L, Elinder CG, Kjellstroem $\mathrm{T}$ and Nordberg GF (eds) Cadmium and Health: $A$ Toxicological and Epidemiological Appraisal. (Vol. 11) Effects of Response. CRC Press, Boca Raton. 257-290.

MERIAN E (ed.) (1991) Metals and their Compounds in the Environment. Occurrence Analysis and Biological Relevance. UCH, Weinheim-New York-Basel-Cambridge.
MILLER JC and MILLER JN (1998) Statistic for Analytical Chemistry (2nd edn.) Ellis Horword, Chichester, Chapter 4.

NJDHSS (1999) New Jersey Department of Health and Senior Services. Hazardous Substance Fact Sheet - Cadmium, Trenton, New Jersey, USA.

PREUSS E and KOLLMANN H (1974) Metallgehalte in Klarschlammen. Natur-wissenschaftler 61 270-274.

PRATER BE (1975) The metal content and characteristics of Steework's effluents discharging to the Tees estuary. Water Pollut. Control 74 63-78.

TSUCHIYA K (1978) Cadmium Studies in Japan - A Review. Kodansha Ltd. Tokyo-Elsevier/North Holland Biomedical Press, Amsterdam-New York-Oxford.

WHO (1996) Guidelines for Drinking Water Quality (2 $2^{\text {nd }}$ edn.) (Vol. 2) Health Criteria and Other Supporting Information. World Health Organisation, Geneva.

USEPA (1989) Risk assessment Guidance for Superfund. (Vol. 1) Human Health Evaluation Manual. Part A. EPA/540/1-89-002. United States Environmental Protection Agency.

VAN LOON JC (1982) Chemical Analysis of Inorganic Constituents of Water. CRC Press. 
